\title{
Consumer Demographics and Modern Formats of Retailing: A Cross-Sectional Study of Impulse Buying and Reasons for Visit Mart in Karachi Pakistan
}

\author{
Sheikh M. Fakhre Alam Siddiqui* Dr. Sohaib Uz Zaman \\ Karachi University Business School, University of Karachi. Main University Road Karachi - 75270. Sindh, \\ Pakistan
}

\begin{abstract}
The purpose of this study is to investigate the effect of important demographic factors on impulse buying behavior of consumer's secondly, the reasons for visiting the departmental stores. The study also examined to understand the major reason(s) that encourage people to visit departmental stores in Karachi. Stratified random sampling was used to select 20 outlets of different chain of departmental stores since the population is homogeneous and classify in different districts of Karachi. 232 respondents were chosen through non-probability convenience sampling for the survey to be carried out via closed-ended and structured questionnaires. Various outlets of Karachi's different departmental store chains were shortlisted so as to gather data from real-time shoppers. For deriving findings, statistical methods such as frequency, chi-square test and simple descriptive techniques were used through SPSS 20.0. The study shows that demographic factors like income and gender have insignificant links with reasons to visit departmental stores while factors like age have significant links with reasons to visit departmental stores. We further concluded that assortment is the key driver of departmental stores followed by discount, convenience and store atmosphere as per our research findings.
\end{abstract}

DOI: $10.7176 / \mathrm{EJBM} / 11-16-10$

Publication date:June $30^{\text {th }} 2019$

\section{INTRODUCTION}

1.1 Background of the Study: Pakistan's recent Economic Survey disclosed that there is an improvement in Pakistan on a qualitative and quantitative basis since $4.24 \%$ growth achieved is broad-based where 2008-09 were the years where the highest growth was achieved. This momentum was maintained due to industry, agriculture and services sectors as they supported a big deal of economic growth. In 2014-15, service sectors' share reached 58.8. Within the services sector, there are 6 sub-sectors which include General Government Services; Transport, Storage and Communication, Housing Services; Finance and Insurance; Wholesale and Retail Trade; and Other Private Services. In the services sector, the performance of growth is broad-based which means that the contribution of every component in the growth is positive accounting at 3.4\%. Researchers and investors get interested in the growth as well as the contribution of Wholesale and Retailing sector in Pakistan's GDP. With the increase in consumer spending, wholesale and retail trade's exponential increasing share multiplied. Furthermore, in the outgoing fiscal year, GDP's $91.04 \%$ was total consumption expenditure. Therefore, due to these such economic sectors serve as a lucrative investment opportunity. Also, the policy rate in the May 2015 lowered by SBP to $7.0 \%$ which is reported by the lowest in the previous 42 years. In this way, investors are eased to borrow money to spend as well as invest respectively.

1.2 Impulsive Buying: This is the unplanned type of decision that is; purchasing a commodity has not been planned previously but, on the spot. One making such purchases is known as an impulsive buyer. When a commodity related to a product is seen by the potential consumer and his passion is stimulated, it is impulse buying. It happens when a powerful and sudden urge is unexpectedly felt by a consumer for purchasing something right away. In the former study, it was found out that is the satisfaction rate will be high; the possibility of purchasing a product impulsively will also be high. The main objective of the research is to find out whether or not does the demographic factors impact impulse buying in Pakistan (a developing country) too as impacts in other countries? Wood et al (1998) reported that abundant researches found out the relationship of impulsive behavior and age. In the US, a researcher scrutinized the age-impulsive buying relationship in an adult sample. According to him, there was a non-linear relationship amid them. He explores that the increased buying tendency is found in 18 to 39 aged people and a decline has been observed in people above 39. Rawlings et al (1995) found out that impulsivity is higher in youngsters as compared to adults. It was also found out by Bellenger et al (1978) that consumers below 35 years of age are more impulsive than the older ones. Mai et al (2003) argued that there is a greater possibility that young people adopt new lifestyles. Fashion, shopping in new markets, buying new products is all enjoyed by them making them a more impulse buyer. Simultaneously, the elders are stable and calm and can have control over spontaneous purchase decisions. 
1.3 Objective of the Study: Many significant developments are being made in Pakistan's retail industry along with its fast growth which includes universal players' entry, modern formats are being accepted, retail formats are being successful and competition in regional markets is raising beyond tier 1 cities and metros. The middle class in today's world go for more options and want to dig-in where core consumers are optimized with numerous dimensions having enhanced shopping experience, time-saving and shopping with recreation and leisure included. The impulse buying tendency of consumers affects the online and in-store purchase favorably resulting in positively impacting the impulse buying urges and positive feelings of consumers, added Beatty and Ferrell (1998). In an impulse buying behavior, there are no such positive feelings. Since the population of the upper-middle-urban class is increasing, there is a possibility that Karachi's shopping markets will be boosted underpinned by robust economic expansions', urbanization's and rising spending powers' paid pace.

\section{REVIEW OF LITERATURE}

Unintentional immediate and sudden purchase either to accomplish a buying task or to buy a particular product is known as impulse buying. It can also be said as an unplanned purchase defined by quick decision making as well as a personal mindset favoring immediate possession.

Prakash and Shrivastava et al (2015) published a paper where there was an endeavor for exploring impulse buying behavior's probability for developing a proper marketing strategy. In the study's outcomes, it was reflected that the impulse buying behavior significantly influenced the demographic characteristics of customers. Unmarried females, as well as males, are reported to have the highest of this behavior since they are responsibility free.

Choudhary (2014) reported that a number of times it happens that the temptation or urge of a person intensifies that he makes a purchase without planning. This not only happens with kids but also happens with adults with rational minds. Factors such as shopper's personal characteristics, discount offers, customer's situation, sales person's behavior, product's nature, product's display, etc. affect a person's impulse buying decision. Impulse behavior is necessary to earn revenue for the mortar and brick retailing. Consequently, all the tactics are attempted by marketers to tap a consumer's impulsive behavior.

A study was carried out by Rana .S (2013) for exploring Income, Education and Gender's effect on the tendency of impulse buying amid Indian consumers in Patiala's shopping malls and authorized retail outlets. Results of his study showed that impulse buying was less influenced by Gender while highly influenced by Income and Education.

A research was carried out by Sarki, Bashir, Sabbar, and Zeeshan in 2013 for comprehending and predicting cultural lifestyle's and values' impact of Pakistani customers on impulse buying behavior. It was found out via results that cultural lifestyle and values' only variable where the existence of male and female customers' significant difference is suggested while buying impulsively is gender. Moreover, it was found out that cultural lifestyle and values' all variables are significantly related to one another. In the results, it was also found out that Pakistani consumers' lifestyles, security, financial satisfaction, life satisfaction, and gender role predict the impulse buying behavior.

Determining how purchasing activities are influenced by different factors' impact is one of the essential most issues that affect profitability. For this, 3 people namely Masouleh, Muradi, and Pazhang (2012) carried out a survey. The purpose of this literature survey is to explore various factors that affect a customer's behavior towards buying a product. The factors were categorized into 3 groups; personal; product and; situation and using an analytical process, they were ranked accordingly. These played an important role in the purchase of a product. The personal element which has demographic characteristics and several other emotional factors were found to be more. Moreover, in demographic characteristics, gender was found to be a more important factor than race and age. They also suggested that situational factors such as culture, staff, and self-services, etc. were also to be considered in impulse buying.

Correspondingly Ekeng, Lifu, and Asinya in (2012) led a study, which also included impulse buying and the impact that consumers' demographic characters had on it. The survey which was conducted supermarkets, market places and around Calabar Metropolis running traffic points, showed that the impetus behind impulse buying was based on a mixture of consumers' demographics characteristics, whereas education had rather a negligible impact. Still, it slightly managed to incline towards consumers' impulse buying behavior. The behavior linked with impulse buying had a sharp distinction in both the consuming genders, with the occurrence gravitating more towards female buyers because of their affinity and impetuous appeal to ornate products, whereas impulse buying and age factor relating to the buyers were linked both substantially and in an inverted manner. In light of this, the study endorses the buyers to arrange their priorities and weigh their preferences in order to avoid buying unnecessary items when purchasing products.

Another study formed a similar basis, conducted by Bashar et al. (2012) in the region of Delhi \& NCR, with demographic factors supporting the foundation. It was based on a formulated questionnaire by customers. It showed a pattern of impulse buying which was more prevalent in youth backed up by a strong financial structure.

The occurrence of impulse buying has intrigued marketers and researchers for decades. However, developing 
countries have mostly worked to scrutinize them. Based on this fact, in (2011) Usman, Jan and Imran went on to figure the linkage of demographic factors with the inclination of customers towards impulse buying, with regard to the urban sector of Peshawar, a city in the developing country of Pakistan. According to their findings, it was revealed that the factor that had a substantial negative link impulse buying inclinations was if age while the factors that showed no such linkage were of income and gender. Therefore they concluded that there was an in a direct impact on the inclination towards impulse buying when it came to demographic variables.

Influence of in-store promotions on impulse buying has been observed by many. A comparative study was carried out by Abratt and Goodey (1990) for examining unplanned buying in South Africa. South Africa's 15 major markets were selected where interviews were taken through shoppers. The discussions in interviews included the way a product's impulse purchase is employed by in-store promotional techniques. Formerly, a study was also carried out by Kollat and Willet (1967) having the same topic but they aimed at comprehending customer intentions while buying impulsively as well as the outcomes. Both studies used similar methodologies. It was also disclosed that the US had more impulse buying behavior than that in South Africa.

\section{RESEARCH METHODOLOGY}

\subsection{Problem Statement}

There are various reasons as to why people make purchase decisions. But there are just two behaviors for making a purchase; an impulse that is, unplanned and; logical that is, planned. People who weigh an item's necessity before purchasing it usually exhibit a logical behavior. There is another behavior known as planned impulse buying where a purchase decision is partially planned. Different sale promotions help to make the decision more determined. While impulse buying is something where a buyer sees the product and gets recalled that he needed it and buys it right away. The present study also evaluates the reasons for visiting the departmental store.

\subsection{Hypotheses}

In the light of above-mentioned literature, the following relation has been developed:

- Ho:Gender does not create the perception of impulse (unthinking) buying. H1:Gender creates a perception of impulse (unthinking) buying.

- Ho: Income does not create the perception of impulse (unthinking) buying.

$\mathrm{H} 2$ : Income creates a perception of impulse (unthinking) buying.

- Ho: Age does not create the perception of impulse (unthinking) buying.

H3: Age creates the perception of impulse (unthinking) buying.

- Ho: Gender does not create the perception of reasons for visiting departmental stores.

- H4: Gender creates the perception of reasons for visiting departmental stores.

- Ho: Income does not create the perception of reasons for visiting the departmental store.

- H5: Income creates the perception of reasons for visiting the departmental store.

- Ho: Age does not create the perception of reasons for visiting the departmental store.

- H6: Age creates the perception of reasons for visiting the departmental store.

\subsection{Selected Variables}

In this research, factors that affect impulse buying and reason for visiting the stores have been discussed, supported with literature reviews. Impulse buying and reasons for visit departmental store as the dependent variable with concern to the independent variables. Gender, income, and age are independent variables. These independent variables are also studied to figure out the reason for visiting the store.

\subsection{Subject and Sampling}

In order to test the above hypotheses, information was collected from selected outlets of 20 different departmental stores at various locations of five different districts of Karachi. The respondents were asked to fill the pre-design approved questionnaires regarding impulse buying and reasons for visiting stores. For the purpose of this study, the following methodology is proposed.

The research was conducted to examine the impulse buying patterns in the departmental stores and the reasons to visit these stores. For this purpose, different branches of "Departmental" stores were officially visited to gather the survey, 232 respondents were surveyed from 20 different outlets. The questionnaire consisted of four sections. The first section was concerned about the respondent profile, while the other three sections held questions to develop a relationship of impulse buying and reasons for visits with respect to assortment, discount, and store 
atmosphere. A five-point Likert scale was used to measure each variable. The questionnaire was derived from past studies of researchers. The sample size of the research conducted is 232, the sample contained real-time shoppers from 20 different outlets of Departmental Super Store in Karachi.

The sampling technique stratified and convenience sampling applied for data collection. A convenience sample is one where the respondents that are selected as the sample are the easiest to access. In our research of more than 20 million urban population of Karachi, we were only interested in achieving a sample size of 232 respondents who would take part in our research. Since the aim of convenience sampling is easy to access, we simply chose to select all 20 outlets where we expected to find a sufficient number of cooperative shoppers.

\subsection{Data Analysis}

Keeping in view the nature of the study, SPSS was used for data analysis. This software helps in data management from the above-mentioned sources, and statistical analysis of the data. Descriptive and Chi-square analysis applied for finding the relationship between consumer demographics (Gender, Age and Income), un-planed shopping and reasons for visiting departmental stores.Chi-square used to measure demographics attitudes of consumer towards modern formats of retailing or shopping behavior.

\section{RESEARCH FINDINGS}

This section highlighted the findings and analysis of key data collected by respondent surveys, such as real-time buyers in several stores. These results have been used to test the hypothesis developed in the first part and the results have been provided at the appropriate points in this section. The following are important points in the results of this study.

\subsection{Respondent profile}

4.1.1 Age: The mean frequency shows that the highest number of respondents was between $21-29$ years $(41.8 \%)$ and 30-39 years (30.6\%), followed by $40-49$ years $12.5 \%$, below 21 years $11.2 \%$ and finally above 50 years of age group least visiting departmental stores that are $3.9 \%$.

Table 1 Distribution of Age

\begin{tabular}{|c|c|c|c|c|c|}
\hline \multicolumn{2}{|c|}{ Age of Respondents } & Frequency & Percent & Valid Percent & Cumulative Percent \\
\hline \multirow{4}{*}{} & under 21 & 26 & 11.2 & 11.2 & 11.2 \\
\cline { 2 - 6 } & $21-29$ & 97 & 41.8 & 41.8 & 53.0 \\
\cline { 2 - 6 } & $30-39$ & 71 & 30.6 & 30.6 & 83.6 \\
\cline { 2 - 6 } & $40-49$ & 29 & 12.5 & 12.5 & 96.1 \\
\cline { 2 - 6 } & over 50 & 9 & 3.9 & 3.9 & 100.0 \\
\cline { 2 - 6 } & Total & 232 & 100.0 & 100.0 & \\
\hline
\end{tabular}

\subsubsection{Gender Mix}

$66.61 \%$ of the respondents were female, while $33.19 \%$ were male.

Table 2 Gender mix

\begin{tabular}{|c|c|c|c|c|c|}
\hline \multicolumn{2}{|c|}{ Gender of Respondents } & Frequency & Percent & Valid Percent & Cumulative Percent \\
\hline \multirow{6}{*}{} & Male & 155 & 66.61 & 66.61 & 66.61 \\
\cline { 2 - 6 } & Female & 77 & 33.19 & 33.19 & 100 \\
\cline { 2 - 6 } & Total & 232 & 100.0 & 100.0 & \\
\cline { 2 - 6 } & & & & & \\
\cline { 2 - 6 } & & & & & \\
\end{tabular}

\subsubsection{Average monthly income}

The highest ratio of the respondents holds average monthly income of PKR 25,000-50,000. i.e. 47.4\%, followed by $51,000-75,000$, i.e. $23.7 \%$, above 100000 , i.e. $12.9 \%, 76000-100000,11.6 \%$.

\section{Table 3 Average Income of respondent}

\begin{tabular}{|c|c|c|c|c|}
\hline & Frequency & Percent & Valid Percent & Cumulative Percent \\
\hline $25000-50000$ & 110 & 47.4 & 49.5 & 49.5 \\
\hline $51000-75000$ & 55 & 23.7 & 24.8 & 74.3 \\
\hline $76000-100000$ & 27 & 11.6 & 12.2 & 86.5 \\
\hline Above & 30 & 12.9 & 13.5 & 100.0 \\
\hline Total & 222 & 95.7 & 100.0 & \\
\hline Missing & 10 & 4.3 & & \\
\hline Total & 232 & 100.0 & & \\
\hline
\end{tabular}




\subsection{Frequency of Visits}

The survey's results also revealed that out of which $53.88 \%$ of people usually visit the stores while $35.78 \%$ of people always visit the stores.

\subsection{Reasons for Visit Departmental Stores}

$51.35 \%$ of the respondents were visited due to the assortment while $29.28 \%$ of the respondents were attracted by discount and $8.11 \%$ because of the store atmosphere.

\subsection{Impulse (unthinking) buying}

There are a huge considerable number of people who buy things that they have not planned. About $72.84 \%$ of the respondents agree that they carryout impulse buying. The most bought category was food items $(65.06 \%)$, followed by personal care $(20.48 \%)$ and clothing $(10.84 \%)$.

\subsection{Environment}

The following outcomes were obtained from a specific checklist of environment-related factors.

- $\quad$ Lighting in the store is pleasant.

- Majority of the respondents (48.28\%) agreed that lighting in the store is pleasant, while $45.26 \%$ strongly agreed.

- The store had helpful employees.

- $\quad 56.71 \%$ agreed and found that the store had helpful employees and $28.14 \%$ strongly agreed.

- It was easy to move about in the store.

- Most of the respondents (39.57\%) agreed that it was easy to move about in the store. $23.91 \%$ strongly agreed with this. Although $23.04 \%$ disagreed because they found it difficult.

- The store had attractive displays.

- Out of all respondents, $55.41 \%$ of respondents agreed that the store had an attractive display and $32.08 \%$ strongly agreed.

- If I see a discount price I tend to buy.

- $49.34 \%$ of respondents were influenced by discount price and they tend to buy if they see discount price. $27.51 \%$ strongly agreed and were attracted to discount prices.

- I found the parking convenient.

- While visiting store $35.65 \%$ agreed that they found the parking convenient. But $28.26 \%$ disagreed and found it difficult.

- I often buy things without thinking.

- $37.22 \%$ of the respondents agreed that they often bought without thinking, while $25.56 \%$ strongly agreed. $19.37 \%$ disagreed and they do not buy without thinking.

- I usually end up spending more money than planned on shopping.

- $42.11 \%$ agreed they usually ended up spending more money than planned on shopping. $29.82 \%$ strongly agreed.

- I usually buy more, when I visit along with my family and friends.

- $44.78 \%$ of respondents strongly agreed that they usually buy more when they visit along with my family and friends. And $41.30 \%$ agreed.

- The transaction process was quick and effective

- $38.26 \%$ agreed that the transaction process was quick and effective. They were satisfied. While $28.26 \%$ disagreed with that.

- Time availability motivates me to make a spontaneous purchase.

- Time availability motivates to make a spontaneous purchase, $43.86 \%$ was agreed.

- I find it convenient to use credit cards while shopping.

- $34.63 \%$ of respondents agreed that they found it convenient to use credit cards while shopping, $23.81 \%$ disagreed with this.

\subsection{Hypotheses Testing and Results}

Ho: Gender does not create the perception of impulse (unthinking) buying.

H1: Gender creates a perception of impulse (unthinking) buying. 


\begin{tabular}{|c|c|c|c|}
\hline \multicolumn{5}{|c|}{ Table 4 Chi-Square Tests } \\
\hline & Value & df & Asymp. Sig. (2-sided) \\
\hline Pearson Chi-Square & $2.546^{\mathrm{a}}$ & 1 & .111 \\
\hline & & & .114 \\
\hline Likelihood Ratio & 2.494 & 1 & .111 \\
\hline Linear-by-Linear Association & 2.535 & 1 & \\
\hline N of Valid Cases & 232 & & \\
\hline
\end{tabular}

Table 4 examines the relationship between gender and impulse buying. The tabulated Chi-Square is 3.841 . Since the tabulated chi-square is greater than the calculated chi-square 2.546, (P-value $>.05$ i.e. 0.111$)$ therefore the Ho is accepted. Hence the gender does not create the perception of impulse (unthinking) buying that shows an insignificant relationship between gender and impulse buying.

Ho: Income does not create the perception of impulse (unthinking) buying.

$\mathrm{H} 2$ : Income creates a perception of impulse (unthinking) buying.

\begin{tabular}{|c|c|c|c|}
\hline \multicolumn{4}{|c|}{ Table 5 Chi-Square Tests } \\
\hline & Value & df & Asymp. Sig. (2-sided) \\
\hline Pearson Chi-Square & $10.090^{\mathrm{a}}$ & 3 & .018 \\
\hline Likelihood Ratio & 11.621 & 3 & .009 \\
\hline Linear-by-Linear Association & 1.959 & 1 & .162 \\
\hline N of Valid Cases & 232 & & \\
\hline \multicolumn{4}{|c}{} \\
\hline
\end{tabular}

Table 5 indicates the relationship between income and impulse buying behavior. The tabulated chi-square represents 7.815. As the calculated chi-square 10.090, (P-value $<0.05$ i.e. 0.018 ) is greater than tabulated chisquare, the Ho is rejected. Therefore, Income creates a perception of impulse (unthinking) buying. It further indicates that income significantly impacts impulse buying behavior.

Ho: Age does not create the perception of impulse (unthinking) buying.

H3: Age creates the perception of impulse (unthinking) buying.

\begin{tabular}{|c|c|c|c|}
\hline \multicolumn{4}{|c|}{ Table 6 Chi-Square Tests } \\
\hline & Value & df & Asymp. Sig. (2-sided) \\
\hline Pearson Chi-Square & $3.926^{\mathrm{a}}$ & 4 & .416 \\
\hline Likelihood Ratio & 4.117 & 4 & .390 \\
\hline Linear-by-Linear Association & .311 & 1 & .577 \\
\hline N of Valid Cases & 232 & & \\
\hline
\end{tabular}

Table 6 examines the relationship between age and impulse buying behavior. The tabulated value for chisquare is 9.488, that is greater than calculated chi-square 3.926, (P-value $>0.05$ i.e., 0.416) hence the Ho is accepted. Therefore, age does not create the perception of impulse (unthinking) buying that shows an insignificant relationship between age and impulse buying.

Ho: Gender does not create the perception of reasons for visiting departmental stores.

H4: Gender creates the perception of reasons for visiting departmental stores.

Table 7Contingency table showing the relationship between gender and reasons for visiting the Department stores

\begin{tabular}{|c|c|c|c|c|}
\hline \multirow{2}{*}{ Reasons } & \multicolumn{4}{|c|}{ Gender } \\
\cline { 2 - 5 } & \multicolumn{2}{|c|}{ Male } & \multicolumn{2}{c|}{ Female } \\
\cline { 2 - 5 } & No & $\%$ & No & $\%$ \\
\hline Discounts & 28 & 36 & 40 & 25.9 \\
\hline Variety of Products & 38 & 48 & 82 & 53.1 \\
\hline Store Atmosphere & 5 & 6.7 & 14 & 8.8 \\
\hline Located near by & 7 & 9.3 & 18 & 12.2 \\
\hline Total & 78 & 100 & 154 & 100 \\
\hline
\end{tabular}

Table 7 examines the relationship between two variables from the departmental store's survey: gender and reasons for visiting the departmental stores. The results also revealed that $48 \%$ of men who go to the mart for variety of products similarly $53.1 \%$ women visiting for same reasons. The store's atmosphere was least influential for both genders. In short table 6 shows the mix results that indicate the gender not specifically relates to the reasons for visiting stores. 


\begin{tabular}{|c|c|c|c|}
\hline \multicolumn{4}{|c|}{ Table 8Chi-Square Tests } \\
\hline & Value & df & Asymp. Sig. (2-sided) \\
\hline Pearson Chi-Square & $2.659^{\mathrm{a}}$ & 3 & .447 \\
\hline Likelihood Ratio & 2.628 & 3 & .453 \\
\hline Linear-by-Linear Association & & & .160 \\
\hline N of Valid Cases & 1.976 & 1 & \\
\hline
\end{tabular}

Table 8 shows the relationship between gender and reasons for visiting departmental stores. The tabulated chi-square is displayed as 7.815 and it is greater than calculated chi-square 2.659, (P-value $>0.05$ i.e. 0.447). Ho is accepted hence gender and reasons for visiting departmental stores are independent. If it further explains than gender and reasons for visiting mart are insignificant.

Ho: Income does not create the perception of reasons for visiting the departmental store.

H5: Income creates the perception of reasons for visiting the departmental store.

Table 9 Contingency table showing the relationship between income and reasons for visiting the Department stores

\begin{tabular}{|c|c|c|c|c|c|c|c|c|c|}
\hline \multirow{2}{*}{ Reasons } & \multicolumn{9}{|c|}{ Income } \\
\cline { 2 - 10 } & 25000 to 50000 & \multicolumn{2}{|c|}{51000 to 75000} & 76000 to 100000 & \multicolumn{1}{c|}{101000 and Above } \\
\cline { 2 - 9 } & No & $\%$ & No & $\%$ & No & $\%$ & No & $\%$ \\
\hline Discounts & 39 & 33.7 & 17 & 28.8 & 5 & 18.5 & 6 & 20.7 \\
\hline Variety of Products & 56 & 48.1 & 30 & 51.9 & 17 & 51.9 & 18 & 62.1 \\
\hline Store Atmosphere & 9 & 7.7 & 3 & 5.8 & 4 & 14.8 & 2 & 6.9 \\
\hline Located near by & 12 & 10.5 & 8 & 13.5 & 3 & 14.8 & 3 & 10.3 \\
\hline Total & 116 & 100 & 58 & 100 & 29 & 100 & 29 & 100 \\
\hline
\end{tabular}

Table 9 examines the relationship between two variables from the departmental store's survey: income and reasons for visiting the departmental stores. The results revealed that around $50 \%$ population of all income groups, who go to the mart for variety of products followed by discounts, convenience and lastly atmosphere.

\begin{tabular}{|l|l|l|l|}
\hline \multicolumn{4}{|c|}{ Table 10 Chi-Square Tests } \\
\hline & Value & df & Asymp. Sig. (2-sided) \\
\hline Pearson Chi-Square & $5.832^{\mathrm{a}}$ & 9 & .757 \\
\hline Likelihood Ratio & 5.678 & 9 & .772 \\
\hline Linear-by-Linear Association & 1.323 & 1 & .250 \\
\hline N of Valid Cases & 232 & & \\
\hline
\end{tabular}

Table 10 indicates the relationship between income and reasons for visiting departmental stores. Since the tabulated chi-square, 16.919 is greater than calculated chi-square 5.832, (P-value $>0.05$ i.e. 0.757) Ho is accepted. Hence income does not create the perception of reasons to visit department stores.

Ho: Age does not create the perception of reasons for visiting the departmental store.H6: Age creates the perception of reasons for visiting the departmental store.

Table 11 Contingency table showing the relationship between age and reasons for visiting the Department store

\begin{tabular}{|c|c|c|c|c|c|c|c|c|c|c|}
\hline \multirow[t]{3}{*}{ Reasons } & \multicolumn{10}{|c|}{ Age } \\
\hline & \multicolumn{2}{|c|}{ Under 21} & \multicolumn{2}{|c|}{21 to 19} & \multicolumn{2}{|c|}{30 to 39} & \multicolumn{2}{|c|}{40 to 49} & \multicolumn{2}{|c|}{50 and Above } \\
\hline & No & $\%$ & No & $\%$ & No & $\%$ & No & $\%$ & No & $\%$ \\
\hline Discounts & 4 & 15.4 & 27 & 30.3 & 17 & 24.6 & 15 & 38.5 & 2 & 22.2 \\
\hline Variety of Products & 18 & 69.2 & 45 & 50.6 & 37 & 53.6 & 21 & 53.9 & 3 & 33.3 \\
\hline Store Atmosphere & 4 & 15.4 & 7 & 7.9 & 5 & 7.3 & 1 & 2.5 & 1 & 11.1 \\
\hline Located near by & 0 & 0 & 10 & 11.2 & 10 & 14.5 & 2 & 5.1 & 3 & 33.3 \\
\hline Total & 26 & 100 & 89 & 100 & 69 & 100 & 39 & 100 & 9 & 100 \\
\hline
\end{tabular}

Table 11 examines the relationship between two variables from the departmental store's survey: age and reasons for visiting the departmental stores. The results revealed that greater than $50 \%$ population of all age groups, who go to the departmental stores for a variety of products followed by again discounts and similarly atmosphere 
is least important. Surprisingly,under 21 age group denied that located nearby is reasons for the visit. The result also revealed that 50 and above age group less attracting towards modern formats of retailing.

Table 12 Chi-Square Tests

\begin{tabular}{|l|l|l|l|}
\hline & Value & df & Asymp. Sig. (2-sided) \\
\hline Pearson Chi-Square & $21.280^{\mathrm{a}}$ & 12 & .046 \\
\hline Likelihood Ratio & 22.220 & 12 & .035 \\
\hline Linear-by-Linear Association & .009 & 1 & .925 \\
\hline N of Valid Cases & 232 & & \\
\hline
\end{tabular}

Table 12 examines the relationship between the age and reasons for visit departmental stores. The tabulated chi-square is 21.026 and as it is smaller than calculated chi-square 21.280, (P-value $<0.05$, i.e. 0.046) Ho is rejected. Therefore, age creates the perception of reasons for visit stores. If further explained under 21 age group shows that nearby location is not important for visiting reasons.

\section{PRACTICAL IMPLICATIONS}

The study has highlighted the importance of the impact of demographic factors on impulse buying behavior of consumers and to visit the departmental store. The findings of this study recommended the organizations and companies to develop the strategies which are beneficial to boost impulsive behavior as well as peaceful environment for consumers.

\section{LIMITATIONS}

The sample size accounts for a very small proportion of the total population under the study and the sample chosen is based solely on the notion of convenience, and can result in under-representation of the large population. The area of the sample was selected from is very narrow, noting of only single metropolitan city Karachi, not taking into account people from a large number of other outlets and stores, and therefore the study results reduce to make a generalization on the whole population.

\section{CONCLUSION}

Impulse buying is a common behavior today. Our culture of consumption enables us to submit to temptation and purchase something without considering the consequences of the buy. Our study identifies the factors (gender, income, and age) affecting the impulse (unthinking) buying and the reasons for visiting the stores. We can conclude our research, in light of our findings that gender does not create the perception of impulse (unthinking) buying. Both males and females were found buying things without thinking (impulse buying). Income creates a perception of impulse (unthinking) buying. People with different income groups perform impulse buying.Age does not create the perception of impulse (unthinking) buying. We found that people from several age groups were performing impulse buying.In short gender and age, insignificant relates to impulse buying whereas income significantly creates the perception of impulse buying.

After carefully examines the relationship between two variables from the departmental store's survey: gender and reasons for visiting the departmental stores. The results also revealed that $48 \%$ of men who go to the mart for variety of products similarly $53.1 \%$ women visiting for same reasons. The store's atmosphere was least influential for both genders. In relation to income and reasons for visiting the departmental stores, results revealed that around $50 \%$ population of all income groups, who go to the mart for variety of products followed by discounts, convenience and lastly atmosphere. For considering age and reasons for visiting the departmental stores, results revealed that greater than $50 \%$ population of all age groups, who go to the departmental stores for a variety of products followed by again discounts and similarly atmosphere is least important. Surprisingly under 21 age group denying that located nearby is reasons for the visit. The result also revealed that 50 and above age group less attracting towards modern formats of retailing. Hence finally we conclude that gender and income are insignificant to reasons for visiting departmental stores and age significantly links we reasons for visiting modern formats of stores.

\section{REFERENCES}

Foroughi, A., Buang, N. A., \&Sadeghi, R. H. M. (2012).Exploring the influence of situational factors (money \& time available) on impulse buying behaviour among different ethics. International Journal of Fundamental Psychology \& Social Sciences, 2(2), 41-44.

Mehta, N., \&Chugan, P. K. (2013). The impact of visual merchandising on impulse buying behavior of consumer: a case from Central Mall of Ahmedabad India.

Chih, W. H., Wu, C. H. J., \& Li, H. J. (2012). The antecedents of consumer online buying impulsiveness on a travel website: Individual internal factor perspectives. Journal of Travel \& Tourism Marketing, 29(5), 430443.

Xiao, S. H., \& Nicholson, M. (2013). A multidisciplinary cognitive behavioural framework of impulse buying: a 
systematic review of the literature. International Journal of Management Reviews, 15(3), 333-356.

Eun Joo Park, Eun Young Kim, Judith Cardona Forney, (2006) "A structural model of fashion-oriented impulse buying behavior", Journal of Fashion Marketing and Management: An International Journal, Vol. 10 Iss: 4 , pp.433 - 446

Foroughi, A., Buang, N. A., \&Sadeghi, R. H. M. (2012).Exploring the influence of situational factors (money \& time available) on impulse buying behaviour among different ethics. International Journal of Fundamental Psychology \& Social Sciences, 2(2), 41-44.

Amos, C., Holmes, G. R., \&Keneson, W. C. (2014).A meta-analysis of consumer impulse buying. Journal of Retailing and Consumer Services, 21(2), 86-97.

Bashir, S., Zeeshan, M., Sabbar, S., Hussain, R. I., \&Sarki, I. H. (2013). Impact of cultural values and life style on impulse buying behavior: a case study of Pakistan. International Review of Management and Business Research, 2(1), 193.

Foroughi, A., Buang, N. A., Senik, Z. C., \&Hajmisadeghi, R. S. (2013).Impulse buying behavior and moderating role of gender among Iranian shoppers. Journal of Basic and Applied Scientific Research, 3(4), 760-69.

Shukla, P., Banerjee, M., \&Adidam, P. T. (2013). The moderating influence of socio-demographic factors on the relationship between consumer psychographics and the attitude towards private label brands. Journal of Consumer Behaviour, 12(6), 423-435.

Mohan, G., Sivakumaran, B., \& Sharma, P. (2013).Impact of store environment on impulse buying behavior. European Journal of Marketing, 47(10), 1711-1732.

Cheng, Y. H., Chuang, S. C., Wang, S. M., \&Kuo, S. Y. (2013). The effect of companion's gender on impulsive purchasing: the moderating factor of cohesiveness and susceptibility to interpersonal influence. Journal of Applied Social Psychology, 43(1), 227-236.

$\mathrm{Xu}, \mathrm{Y}$. (2013). Impact of store environment on adult generation Y consumers' impulse buying. Journal of Shopping Center Research, 14(1), 39-56.

Estelami, H., Lehmann, D. R., \& Holden, A. C. (2001). Macro-economic determinants of consumer price knowledge: A meta-analysis of four decades of research. International Journal of Research in Marketing, 18(4), 341-355.

Verplanken, B., \& Sato, A. (2011). The psychology of impulse buying: An integrative self-regulation approach. Journal of Consumer Policy, 34(2), 197-210.

Piron, F. (1991).Defining impulse purchasing. NA-Advances in Consumer Research Volume 18.

Beatty, S. E., \& Ferrell, M. E. (1998). Impulse buying: Modeling its precursors. Journal of retailing, 74(2), 169191.

Ghani, U., Imran, M., \& Jan, F. A. (2011). The impact of demographic characteristics on impulse buying behavior of urban consumers in Peshawar. International Journal of Academic Research, 3(5), 286-289.

Bhuvaneswari, M. V., \& Krishnan, J. (2016). A Study on the Impact of Demographic Factors On Impulse Buying Behaviour of Consumers in Chennai City. PARIPEX-Indian Journal of Research, 4(11).

Prakash, G., Prakash, S., \&Shrivastava, A. (2015). Demographics and Determinants of Impulse Buying Behaviour: A Comparative Analysis of Male and Female Customers. Journal of Management Research and Analysis, 2(2), 169-172.

Choudhary, S. (2014).Study of Impulse Buying Behavior of Consumers. International Journal of Advances Research in Computer Science and Management Studies, 2(9), 1-4.

Bashir, S., Zeeshan, M., Sabbar, S., Hussain, R. I., \&Sarki, I. H. (2013). Impact of cultural values and life style on impulse buying behavior: a case study of Pakistan. International Review of Management and Business Research, 2(1), 193.

Masouleh, S., Pazhang, M., \&Moradi, J. (2012). What is Impulse Buying? An analytical network processing framework for prioritizing factors affecting impulse buying. Management Science Letters, 2(4), 1053-1064.

Ekeng, A. B., Lifu, F. L., \&Asinya, F. A. (2012).Effect of demographic characteristics on consumer impulse buying among consumers of Calabar municipality, cross river state.Academic Research International, 3(2), 568 .

Mittal, S., Chawla, D., \&Sondhi, N. (2016).Segmentation of impulse buyers in an emerging market-An exploratory study. Journal of Retailing and Consumer Services, 33, 53-61.

Kalla, S. M., \& Arora, A. P. (2011). Impulse buying: A literature review. Global Business Review, 12(1), 145157. 